\title{
Identiti Adalet Ve Kalkinma Partisi (AKP) Turki di Persimpangan: Parti Islam atau Sekular?
}

\author{
The Identity of Turkey's Adalet ve Kalkınma Partisi (AKP) at the Crossroads: \\ Islamic or Secular Party?
}

\author{
WAN KAMAL MUJANI* \& MUHAMMAD KHALIS IBRAHIM ${ }^{1}$
}

\begin{abstract}
The Adalet ve Kalkınma Partisi (AKP) which has a tendency towards Islam, but secular concurrently raises a question: what is the identity of the AKP? To date, this question is still being debated although generally, AKP has frequently been denoted as a party with an Islamic aspiration. Hence, this paper aims to revisit the identity of the AKP based on the framework of Islamic political movement. This paper fully adopted library research by examining sources related to the scope of the discussion. Ideologically, AKP makes conservative democracy as its ideology by harmonizing between conservative and liberal democratic values. The party also adheres to the secularism discourse although it meets almost all the characteristics of Islamic political movement for the Turkish context. Besides, it was found that the AKP has sided to religious interests in few issues. At the same time, AKP also has been resisted by military as the guardian of secular principle. This paper argues that the AKP is a party of its own identity, where it upholds the liberal version of secularism and tends to create an accommodative atmosphere for free religious practice. Finally, this paper offers some recommendations that can be considered for future studies.
\end{abstract}

Keywords: AK Party, Islamism, political Islam, politics of Turkey, secularism

Seperti negara-negara Muslim yang lain, Turki turut tidak terkecuali daripada menjadi subjek perbahasan seputar hubungan Islam, demokrasi, dan kenegaraan. Malah, pengalaman Turki memperlihatkan keunikannya yang tersendiri lantaran ia merupakan sebuah negara sekular namun pada masa yang sama, berpenduduk majoriti Muslim. Dalam hal ini, entiti-entiti yang mempunyai aspirasi agama sering menjadi tumpuan kerana peranannya dalam mengangkat kepentingan agama dalam urustadbir negara. Di Turki, entiti-entiti beraspirasi Islam, khususnya yang bergerak sebagai gerakan sosial, telah wujud sejak Turki berada pada fasa awal penubuhannya. Antara gerakan Islam terawal yang wujud sejak penubuhan negara Turki moden ialah Gerakan Nurcu yang menerima inspirasi daripada idea-idea Badi'uzzaman Sa'id Nursi yang hidup antara 1877 dan1960 (Vahide 2011). Kemudian, gerakan Islam bercorak politik mula mengambil tempat selepas sistem politik pelbagai parti dilaksanakan bermula pada tahun 1947 . Sejak itu, gerakan Islam bercorak politik atau gerakan politik Islam yang dirintis oleh Necmettin Erbakan mula menyertai secara aktif persaingan demokrasi di Turki.

Lantaran Turki mengamalkan sekularisme secara keras, gerakan-gerakan Islam, baik yang beroperasi sebagai gerakan sosial mahupun gerakan politik, telah menerima tentangan yang

\footnotetext{
${ }^{1}$ Wan Kamal Mujani* (corresponding author), Ph.D., professor at Research Centre for Arabic Language and Islamic Civilization, Faculty of Islamic Studies, Universiti Kebangsaan Malaysia, 43600 BANGI, Selangor, Malaysia, email: inawan@ukm.edu.my; Muhammad Khalis Ibrahim, M.A., Ph.D. candidate at Department of History and Islamic Civilization, Academy of Islamic Studies, Universiti Malaya, 50603 WILAYAH PERSEKUTUAN KUALA LUMPUR, email: khalismuhammad92@yahoo.com.
} 
hebat daripada pendokong sekular, khususnya tentera. Gerakan-gerakan tersebut telah dilumpuhkan dan diharamkan setelah pihak tentera berjaya mengesan komitmen mereka dalam agenda memartabatkan semula Islam di Turki. Di mata pendokong sekular, gerakan-gerakan beraspirasi Islam dilihat sebagai 'ancaman' kerana dianggap menggugat keamanan negara dan sekaligus mencabar prinsip sekularisme yang tidak boleh dikompromi sama sekali.

Pengharaman gerakan sosial dan parti politik yang berasaskan Islam telah menjadi pencetus kepada penubuhan Adalet ve Kalkınma Partisi (Parti Keadilan dan Pembangunan-AKP) oleh Recep Tayyip Erdoğan dan kelompok reformis dari gerakan politik Islam Erbakan. AKP memperlihatkan prestasi yang cemerlang dengan memenangi kesemua pilihan raya umum dan pilihan raya tempatan yang disertainya sejak tahun 2002. Berbeza dengan entiti-entiti Islam sebelumnya yang lebih menzahirkan aspirasi Islam dalam perjuangan mereka, Erdoğan memilih untuk tidak menzahirkan aspirasi Islam dalam kegiatan-kegiatan AKP. Malah, Erdoğan lebih menonjolkan AKP sebagai sebuah parti yang menjunjung demokrasi dan hak asasi serta berkompromi dengan sekularisme (Sambur 2009). Namun, AKP tidak dapat lari daripada sejarah susur-galurnya yang mempunyai kaitan dengan gerakan Islam sebelumnya. Hakikatnya, AKP merupakan parti serpihan daripada perpecahan Gerakan Milli Görüş (Wawasan Kebangsaan) yang dipimpin oleh Erbakan.

AKP yang dilihat cenderung kepada Islam namun mesra-sekular pada masa yang sama menimbulkan persoalan: apakah sebenarnya identiti AKP? Adakah AKP merupakan sebuah entiti Islam atau sekular? Sehingga kini, persoalan ini masih menjadi perdebatan meskipun secara umumnya, AKP sering dianggap sebagai sebuah parti beraspirasi Islam. Justeru, makalah ini bertujuan untuk menilai semula identiti AKP berdasarkan kerangka gerakan politik Islam. Penilaian akan dibuat dengan meneliti tiga aspek utama iaitu: i) Ideologi AKP, bagi memberi gambaran mengenai wacana atau paradigma parti tersebut; ii) Sikap terhadap beberapa isu, merupakan terjemahan praktikaliti kepada ideologi yang dianuti; serta iii) Cabaran yang dihadapi, merupakan cerminan respons daripada pihak yang berseteru dengan AKP, sekaligus turut menjelaskan di pihak manakah AKP berada. Makalah ini mempunyai dua sumbangan utama terhadap literatur. Pertama, ia cuba menilai identiti AKP secara lebih berobjektif dan tidak semata-mata melihat kepada satu faktor, misalnya susur-galur sejarah, dalam membuat penilaian. Kedua, makalah ini menawarkan pandangannya yang tersendiri, dan sekaligus turut menjadi alternatif kepada pandangan sedia ada, mengenai identiti AKP yang masih lagi diperdebatkan sehingga kini. Makalah ini berasaskan kajian kepustakaan sepenuhnya dengan meneliti pelbagai sumber yang berkaitan dengan skop perbincangan. Ia dimulai dengan perbincangan mengenai ideologi AKP dan diikuti sikap terhadap beberapa isu terpilih. Kemudian, perbincangan akan menjurus kepada cabaran yang dihadapi oleh AKP sebelum melakukan refleksi terhadap identiti AKP berdasarkan tiga aspek di atas. Perbincangan diakhiri dengan kesimpulan serta beberapa cadangan yang boleh dipertimbangkan untuk kajian-kajian di masa akan datang.

\section{Gerakan Politik Islam dalam Konteks Turki}

Persoalan mengenai gerakan politik Islam iaitu entiti yang memperjuangkan idea political Islam, telah dihuraikan oleh ramai pengkaji lepas. Antaranya, Muhamad Razak (2016) mendefinisikan gerakan politik Islam sebagai gerakan idea yang bersifat massa, berkembang bagi mempromosikan sebuah tasawwur berfikir baru tentang tatacara, etika dan nilai kehidupan masyarakat dan negara yang dinamik dan sistematik sejajar dengan tuntutan ajaran agama Islam yang luhur dan sejagat. Fuller (2003) pula menghuraikan gerakan politik Islam sebagai suatu fenomena yang tidak bersifat eksotik dan terasing, sebaliknya mempunyai hubungan dengan isuisu politik, sosial, ekonomi dan moral kontemporari. Manakala Denoeux (2002) menghujahkan gerakan politik Islam sebagai entiti yang memberikan penyelesaian secara politik terhadap permasalahan-permasalahan masyarakat hari ini. Walaupun gerakan politik Islam dilihat banyak 
merujuk kepada khazanah tradisi Islam dari sudut asas teori, ia tidak bermaksud gerakan politik Islam bercita-cita untuk membina semula tamadun Islam klasik, sebaliknya meletakkan matlamat membina tamadun Islam kontemporari, baharu, dan sesuai dengan konteks semasa.

Dalam membincangkan mengenai asal-usul gerakan politik Islam, Maszlee (2016) menyebut bahawa gerakan Islam abad moden merupakan kesinambungan daripada Khilafah Uthmaniyyah yang telah terbubar, di mana perjuangannya pada peringkat awal menjurus kepada penegakkan semula Khilafah, menentang penjajah yang secara umumnya terdiri daripada negara-negara Barat serta menuntut kemerdekaan tanah air. Pada fasa ini juga, penentangan gerakan politik Islam terhadap kuasa kolonial bukan sahaja disebabkan oleh penjajahan wilayah yang dilakukan, akan tetapi turut melibatkan kritikan terhadap pengaruh pemodenan acuan Barat yang bercirikan rasional dan sekular semata-mata ke atas dunia Islam. Selepas merdeka daripada penjajah, orientasi perjuangan gerakan politik Islam tertumpu pula kepada pemerintah sekular tempatan yang mewarisi kuasa kolonial, di samping aktif dengan kerja-kerja kebajikan dan kesukarelawanan. Namun, tekanan telah dikenakan oleh pemerintah tempatan yang berpegang kepada kerangka idea sekular ke atas gerakan politik Islam. Hal ini menyebabkan mereka memberi reaksi yang pelbagai terhadap tekanan-tekanan yang dihadapi (Ahmad Munawar et al. 2008). Ayoob (2008) menyatakan bahawa suasana setempat, termasuk tekanan oleh rejim pemerintah, menyebabkan setiap gerakan politik Islam mengadaptasi pendekatan yang berbeza, lantas menjadikan mereka hadir sebagai entiti pelbagai wajah. Ini bermaksud, subjek mengenai gerakan politik Islam itu sendiri tidak sewajarnya digeneralisasikan berdasarkan corak atau orientasi tertentu. Sebaliknya, penelitian secara spesifik terhadap setiap satu gerakan politik Islam perlu dilakukan memandangkan setiap daripadanya mempunyai kelainan dan ciri-ciri yang tersendiri, termasuklah bagi konteks gerakan politik Islam di Turki.

Bagi konteks Turki, latar belakang sejarah dan budaya masyarakatnya mempunyai keunikan yang tersendiri. Menurut Uğur (2004), wacana tradisi berupa teologi Maturidiah, mazhab Hanafi serta tarekat Sufi telah mewarnai masyarakat muslim Turki sejak era Uthmaniyyah lagi dan mempengaruhi pendekatan beragama masyarakat sehingga mereka cenderung terhadap sikap inklusif dan toleransi. Dalam hal ini, idea teologi Maturidiah yang menekankan aspek logik mempunyai peranannya dalam membentuk cara berfikir kritis masyarakat Turki pada era moden. Mazhab Hanafi pula menekankan elemen rasional dan universal, di mana kesannya pada era kontemporari dapat dilihat menerusi sikap toleransi dan meraikan nilai kepelbagaian masyarakat Turki. Manakala elemen Sufi yang mewarnai tradisi masyarakat Turki mengalami proses evolusi bagi merespons cabaran sekularisme. Proses evolusi tersebut telah melahirkan masyarakat Turki yang sabar dalam menghadapi cabaran dengan mengalihkan tumpuan kesabaran tersebut kepada aktiviti-aktiviti kebajikan dan kemanusiaan. Wacana tradisi Turki terus bersebati sebagai norma berfikir dan amali masyarakat Turki meskipun proses sekularisasi telah dilaksanakan secara giat sejak awal penubuhan negara tersebut. Ia turut melahirkan masyarakat yang cenderung kepada sikap rasional dan tidak berkonfrontasi dengan elit sekular secara langsung, di mana sikap tersebut turut mempengaruhi pendekatan gerakan politik Islam di Turki dan menjadikan ia unik berbanding gerakan politik Islam di negara-negara yang lain (Ahmad Dzakirin 2012).

Selain itu, faktor kekangan perundangan yang melarang sebarang organisasi atau parti politik untuk menjadikan Islam sebagai identifikasi pertubuhan turut mempengaruhi corak gerakan politik Islam di Turki. Senario ini menjadikan mereka tidak menzahirkan jenama Islam sama ada pada batang tubuh mahupun ideologi organisasi, sebaliknya lebih menerapkan nilainilai Islam secara praktikal berasaskan konsep Ahlak ve Fazilet (akhlak dan kebaikan). Oleh kerana itu, parti-parti politik Islam di Turki menggunakan nilai-nilai keislaman seperti Selamet (keselamatan atau kesejahteraan), Refah (kebajikan), Fazilet (kebaikan), Saadet (kebahagiaan) dan Adalet (keadilan) bagi mengidentitikan parti-parti mereka. Nilai-nilai ini turut tercermin pada pendekatan gerakan politik Islam di Turki yang lebih menekankan elemen Hizmet (perkhidmatan) berbanding retorik negara Islam yang lebih bersifat ideological. 
Dengan ini, gerakan politik Islam bagi konteks Turki dapat dirumuskan seperti berikut: i) ia merupakan gerakan bersifat massa dengan mengemukakan penyelesaian kepada isu-isu politik, ekonomi, dan sosial, ii) ia berada di atas jalur arus perdana yang tidak terasing daripada masyarakat, iii) ia dilatar belakangi oleh wacana tradisi yang bersifat akomodatif dan inklusif, dan iv) ia lebih menekankan aspek praktikal berbanding ideologikal, meskipun aspirasi Islam tidak sama sekali dipinggirkan. Ciri-ciri ini merupakan subjek yang penting bagi mengukur sejauh mana ideologi AKP selari dengan ideologi gerakan politik Islam bagi konteks Turki.

\section{Pasca Islamisme}

Pasca Islamisme merupakan satu lagi kerangka yang wajar untuk dipertimbangkan dalam menganalisis ideologi AKP. Istilah pasca Islamisme mula-mula diperkenalkan oleh Asef Bayat (1996) bagi merujuk kepada peralihan wacana gerakan politik Islam berdasarkan pemerhatiannya terhadap perubahan wacana politik Islam di Iran. Menurut beliau, pasca Islamisme merupakan satu fenomena baharu di mana simbol dan imej Islam semakin dipudarkan oleh kelompok pendukung Islam. Sebaliknya, perjuangan mereka disebatikan dengan sentimen hak asasi, demokrasi dan kemodenan. Dengan erti kata lain, kelompok yang mendukung Islam semakin meninggalkan citra dan retorik politik dan aktivisme Islam sebelumnya (yang dilabel sebagai Islamisme), lantas mengambil sikap yang lebih pragmatik berdasarkan keperluan semasa. Bayat (2005) kemudian mengembangkan lagi pengolahan mengenai pasca Islamisme dengan menjelaskan faktor kepada perubahan wacana yang berlaku. Menurutnya, perubahan pendekatan gerakan politik Islam daripada bersifat konservatif dan fundamentalis kepada yang lebih liberal adalah disebabkan ruang wacana yang mengalami perubahan yang turut menuntut kepada proses tafsiran semula perjuangan gerakan politik Islam. Hal ini termasuklah dengan melakukan tafsiran semula terhadap konsep negara Islam dan pelaksanaan undang-undang syariah yang menjadi agenda teras kepada perjuangan gerakan politik Islam sebelumnya.

Ahmad Sunawari (2017) telah mengembangkan lagi perbincangan mengenai konsep pasca Islamisme dalam melakukan pemerhatian terhadap perkembangan kebangkitan semula Islam sekitar tahun 1970-an sehingga 1980-an. Menurutnya, pasca Islamisme merupakan kesinambungan daripada fenomena kebangkitan tersebut. Dalam hal ini, kegagalan agenda kebangkitan semula Islam yang lebih menekankan retorik ideologikal telah dikritik pada fasa pasca Islamisme yang kemudiannya cuba untuk mengisi kelompangan yang ditinggalkan oleh generasi kebangkitan semula Islam. Bagi mengisi kelompangan tersebut, gerakan politik Islam memikirkan bahawa perlu bagi mereka untuk memastikan survival perjuangan mereka terus dipelihara. Justeru, wujudnya keperluan bagi gerakan politik Islam untuk beralih kepada wacana yang lebih inklusif dan mudah difahami oleh masyarakat memandangkan persaingan di pentas demokrasi dan sistem pilihan raya turut mendesak mereka untuk merealisasikan cita-cita di dalam ruang yang lebih liberal dan bebas ideologi (Wan Ahmad Fahmi 2017).

Berdasarkan huraian di atas, gerakan politik Islam dalam konteks Turki dilihat mempunyai keselarian dengan fenomena pasca Islamisme. Ciri-ciri pasca Islamisme seperti simbol dan imej Islam yang dipudarkan, penyisihan retorik ideologikal serta penekanan kepada aspek nilai kelihatan selari dengan wacana gerakan politik Islam dalam konteks Turki. Di sini timbul persoalan bahawa adakah ideologi gerakan politik Islam di Turki sebenarnya adalah pasca Islamisme? Penulis berpandangan, meskipun terdapat persamaan antara keduanya, namun ideologi gerakan politik Islam dalam konteks Turki dan pasca Islamisme dibentuk berdasarkan ciri-ciri yang tersendiri. Bagi gerakan politik Islam dalam konteks Turki, ia masih lagi mengekalkan ciri-ciri gerakan politik Islam meskipun bentuk wacananya yang agak longgar berbanding idea asal gerakan politik Islam. Sebaliknya, pasca Islamisme pula merupakan penyimpangan daripada idea asal gerakan politik Islam, meskipun ia terbit daripada wacana gerakan politik Islam itu sendiri. Gerakan politik Islam merupakan fenomena yang bukan monolitik dan dicorakkan oleh realiti dan konteks setempat. Justeru, wacana gerakan politik 
Islam di Turki yang longgar daripada ideologi perlu dilihat berdasarkan realiti dan konteks di Turki dan tidak sewajarnya digeneralisasi mengikut satu kerangka yang tertentu.

\section{Demokrasi Konservatif}

Dari sudut sejarah, AKP merupakan serpihan daripada induknya iaitu Gerakan Milli Görüş. Walau bagaimanapun, strategi dan pendekatan yang diambil oleh AKP adalah berbeza dengan partiparti Islam sebelumnya. Erdoğan selaku pemimpin utama AKP lebih memilih untuk mewajahkan parti tersebut sebagai sebuah parti berideologi konservatif demokrasi yang menjunjung nilainilai demokrasi liberal berbanding sebagai sebuah parti yang berasaskan agama. Sebagai sebuah parti konservatif demokrat, AKP menyasarkan matlamat bagi mewujudkan Turki yang demokratik serta mengharmonikan nilai-nilai konservatisme seperti aspek moral, budaya dan identiti nasional dengan elemen demokrasi, pasaran bebas, kepelbagaian, kedaulatan undangundang dan hak asasi (Sambur 2009). Konservatif demokrasi meletakkan kepentingan untuk terus memelihara asas-asas yang membentuk negara dan bangsa Turki seperti budaya dan identiti keagamaan walaupun pada masa yang sama, pembentukan negara Turki yang lebih liberal, progresif dan demokratik turut digerakkan (Yıldız 2010; Alahmed \& Wan Kamal 2015).

Walaupun cenderung untuk memelihara elemen-elemen konservatisme, ini tidak bermaksud AKP menolak keberadaan sekularisme sebagai identiti negara Turki. Berbeza dengan parti-parti berorientasikan Islam sebelumnya yang melihat sekularisme sebagai ancaman, AKP pula memilih untuk mengiktiraf sekularisme dan komited untuk terus memelihara identiti sekularisme Turki. Sekularisme dianggap sebagai prinsip politik semata-mata dan tidak berkait dengan perwatakan serta gaya hidup individu. Oleh itu, ia tidak menjejaskan hak rakyat Turki untuk terus mengamalkan pegangan hidup dan agama yang dianuti tanpa dikongkong oleh sesiapa, meskipun negara atau parti yang disertainya bersifat sekular (Sambur 2009; Ahmad Dzakirin 2012). Justeru, AKP menolak pengeksploitasian agama dalam urusan politik dan kenegaraan, sebaliknya berpandangan bahawa agama perlulah tertakluk di bawah urusan peribadi. Malah, Erdoğan (2004) sendiri berpandangan bahawa sekularisme sebagai elemen penting untuk mencapai pentadbiran yang lebih demokratik kerana melihat sekularisme yang sebenarnya menjamin nilai kepelbagaian dan kebebasan. Untuk mencapai kebebasan yang dimaksudkan, tafsiran baru mengenai sekularisme yang lebih liberal dan meraikan hak asasi cuba dikemukakan oleh AKP bagi menolak sekularisme yang bersifat autoritarian atau keras, iaitu bentuk sekularisme yang menjadi pegangan pendokong sekular sebelumnya (Yıldız 2010). Ini kerana dalam konteks Turki, "pendokong sekular" merujuk kepada mereka yang berpegang kepada gagasan sekular Kemalisme iaitu gagasan yang diperkenalkan oleh pengasas negara Turki moden, Mustafa Kemal Atatürk. Pendokong idea Kemalisme pula seringkali dirujuk sebagai "Kemalis". Pengkategorian ini adalah penting bagi membezakan pendokong sekularisme alaKemalisme daripada pendokong idea sekularisme yang lebih liberal dan sederhana sepertimana yang cuba ditonjolkan oleh AKP.

Penafsiran semula sekularisme berdasarkan perspektif kebebasan dan hak asasi menyebabkan usaha pendemokrasian serta penyertaan Turki ke dalam Kesatuan Eropah (European Union-EU) sebagai agenda utama AKP. Berbeza dengan perspektif pendokong sekular untuk menyertai EU sebagai sebahagian daripada proses bagi 'membaratkan' Turki, AKP pula menjadikan agenda tersebut sebagai proses untuk mewujudkan Turki yang lebih liberal dan menjamin nilai demokrasi. Kriteria Copenhagen sebagai syarat yang ditetapkan bagi sesebuah negara untuk menyertai EU menjamin nilai-nilai kebebasan dan dijadikan asas kepada usaha pendemokrasian tersebut (Alahmed et al. 2015). Dasar pragmatik yang diamalkan menjadikan AKP berusaha untuk memenuhi tuntutan popular rakyat yang menginginkan suasana politik yang lebih demokratik dan bebas di Turki.

Antara usaha pendemokrasian yang dilaksanakan oleh AKP dan signifikan dari sudut impak ialah usaha pindaan Perlembagaan Turki pada tahun 2010. Pada Mac 2010, AKP telah 
mengusulkan pakej pindaan perlembagaan yang boleh memberi kesan kepada 26 artikel di dalam Perlembagaan Turki. Cadangan pindaan tersebut adalah bertujuan bagi memperkasakan sistem demokrasi di Turki supaya selari dengan aspirasi EU di samping memecahkan monopoli kelompok sekular di dalam badan kehakiman dan institusi tentera yang selama ini menjadi penghalang kepada usaha pendemokrasian (Özbudun 2012). Pindaan yang diusulkan telah berjaya dilaksanakan hasil sokongan majoriti rakyat menerusi referendum di peringkat nasional pada 12 September 2010 (Wan Kamal et al. 2015).

\section{Sikap dan Dasar AKP Dalam Beberapa Isu Penting}

Dalam bahagian ini, perbincangan akan menjurus kepada sikap dan dasar AKP terhadap beberapa isu penting bagi melihat sejauh mana parti tersebut mempunyai kaitan dengan idea gerakan politik Islam secara praktikal. Penulis menumpukan perbincangan kepada dua isu utama iaitu larangan bertudung dan kedudukan pendidikan agama. Dua isu ini diberikan perhatian kerana kedua-duanya merupakan isu yang sering mendapat perhatian gerakan politik Islam di Turki. Lantaran itu, kedua-duanya merupakan indikator yang penting bagi menilai sikap AKP terhadap kedua-dua isu tersebut.

\section{Sikap AKP Terhadap Larangan Bertudung}

Di Turki, pemakaian tudung pernah menjadi isu yang mengundang perdebatan antara pendokong Islam-konservatif dan pendokong sekular. Larangan bertudung telah dilaksanakan secara rasmi sejak tahun 1978, bermula di institusi-institusi awam dan seterusnya universiti-universiti seluruh negara. Larangan tersebut dikuatkuasakan di atas alasan tudung dianggap sebagai simbol agama yang bercanggah dengan prinsip sekularisme (Cindoglu \& Zencirci 2008).

Sepertimana kebanyakan pendokong Islam sebelumnya, AKP secara umumnya turut menentang larangan bertudung. Bagi AKP, pemakaian tudung merupakan hak bagi kaum wanita yang tidak boleh dinafikan (Köni \& Açikgöz 2013). Secara asasnya, penghujahan AKP dalam isu ini adalah selari dengan aspirasi sekular parti tersebut yang memperjuangkan nilai liberal dan kebebasan. Berdasarkan idea sekularisme AKP, penentangannya terhadap larangan bertudung dapat difahami menerusi tiga perspektif. Pertama, sekularisme sewajarnya hanya melibatkan pemisahan agama di peringkat negara, bukan di peringkat individu. Ini bermaksud, pemakaian tudung yang merupakan hak individu tidak boleh dinafikan. Kedua, tudung dilihat sebagai subjek neutral yang tiada sebarang kaitan dengan agenda politik mahupun usaha mengembalikan semula syariah Islam di Turki. Oleh itu, ia tidak sepatutnya dilihat bercanggah dengan prinsip sekularisme negara. Ketiga, sekularisme sepatutnya berperanan memelihara hak asasi individu, termasuklah hak untuk memakai tudung, dan bukan sebaliknya.

Berhubung larangan bertudung, beberapa inisiatif telah dilakukan oleh AKP bagi menzahirkan penolakan terhadap larangan tersebut. Inisiatif pertama telah dirintis pada Februari 2008 bagi memansuhkan larangan bertudung menerusi cubaan meminda dua artikel di dalam Perlembagaan Turki iaitu Artikel 10 (memperuntukkan kesaksamaan undang-undang terhadap semua rakyat Turki tanpa diskriminasi) dan Artikel 42 (memperuntukkan hak semua rakyat Turki untuk memperoleh pendidikan) (Özbudun 2012). Pindaan yang dicadangkan adalah untuk memberi ruang kepada mahasiswi menikmati peluang pendidikan sepertimana pelajarpelajar yang lain, walaupun mereka bertudung. Pindaan tersebut telah menerima sokongan majoriti 411 daripada 550 ahli parlimen serta pengesahan oleh Presiden Turki ketika itu; Abdullah Gül. Walau bagaimanapun, wakil daripada Cumhuriyet Halk Partisi (Parti Republikan Rakyat-CHP) iaitu parti sekular pro-Kemalis telah mengemukakan aduan kepada Mahkamah Perlembagaan supaya keputusan tersebut dibatalkan. Pada 5 Jun 2008, sembilan daripada sebelas hakim Mahkamah Perlembagaan memutuskan bahawa keputusan bagi meminda Artikel 10 dan Artikel 42 adalah terbatal kerana bertentangan dengan prinsip sekularisme yang 
termaktub di dalam perlembagaan. Keputusan tersebut menyebabkan AKP terpaksa menarik semula cadangan pindaan yang dikemukakan (Saktanber \& Corbacioğlu 2008). Usaha memansuhkan larangan bertudung sememangnya suatu usaha yang berisiko buat AKP. Pada Mac 2008, Pendakwa Raya Awam telah mengemukakan aduan kepada Mahkamah Perlembagaan untuk mengaitkan AKP dengan kegiatan anti-sekular berikutan cubaan meminda perlembagaan bagi membenarkan pemakaian tudung. Jika didapati bersalah, AKP terpaksa berhadapan dengan tindakan pengharaman parti. Walau bagaimanapun, sokongan minimum tiga perlima panel hakim, atau bersamaan tujuh daripada sebelas panel hakim yang membolehkan pembubaran sesebuah parti politik tidak dapat dicapai berikutan hanya enam orang hakim sahaja yang menyokong pembubaran tersebut. Mahkamah Perlembagaan akhirnya memutuskan bahawa AKP tidak dibubarkan, sebaliknya dikenakan tindakan pengurangan peruntukan parti (Özbudun 2012).

Kegagalan usaha yang dilakukan pada tahun 2008 tidak mengendurkan hasrat AKP untuk memansuhkan larangan bertudung. Inisiatif seterusnya dilakukan menerusi usaha pendemokrasian yang dilancarkan pada 30 September 2013 (selepas ini dirujuk sebagai 'Inisiatif Pendemokrasian 2013'). Inisiatif Pendemokrasian 2013 diumumkan oleh Erdoğan, ketika itu sebagai Perdana Menteri Turki, dengan memperincikan mengenai reformasi sistem politik, hukuman jenayah, hak asasi dan pendidikan (AK PARTI 2015). Inisiatif pendemokrasian tersebut telah membuka laluan kepada pemansuhan larangan bertudung yang terkandung di dalam Undang-undang Pakaian di institusi-insitusi awam dan universiti. Bermula 8 Oktober 2013, pemakaian tudung adalah dibenarkan di institusi awam dan universiti selepas kebenaran tersebut diwartakan secara rasmi (Akoglu 2015).

Secara dasarnya, usaha pemansuhan larangan bertudung yang dilakukan pada tahun 2008 dengan tahun 2013 mempunyai perbezaan khususnya dari sudut pendekatan yang diambil. Pada tahun 2008, cubaan AKP untuk meminda Artikel 10 dan Artikel 42 di dalam Perlembagaan Turki telah dibatalkan oleh Mahkamah Perlembagaan kerana didakwa bercanggah dengan prinsip sekularisme. Manakala pendekatan yang diambil pada tahun 2013 adalah berbeza bilamana AKP menjadikan inisiatif pendemokrasian sebagai mekanisme bagi mencapai objektif pemansuhan larangan bertudung. Dalam hal ini, pendekatan berasaskan pendemokrasian lebih berkesan lantaran usaha pendemokrasian merupakan kehendak popular rakyat bagi memastikan Turki menjadi lebih demokratik dan berupaya menyertai EU. Tambahan pula, siri pendemokrasian yang dilakukan bagi tempoh antara tahun 2008 sehingga 2013, lebih-lebih lagi menerusi pindaan Perlembagaan Turki pada tahun 2010, telah mereformasikan struktur badan kehakiman. Perkembangan ini telah mempengaruhi tafsiran Mahkamah Perlembagaan terhadap perlembagaan berbanding sebelumnya (Oztig 2018).

\section{Sikap AKP Terhadap Kedudukan Pendidikan Agama}

Sepertimana pemakaian tudung, kedudukan pendidikan agama turut mengundang polemik dan pertikaian di Turki. Dalam konteks pendidikan agama di Turki, perdebatan banyak berpusat kepada status Sekolah Imam-Hatip selaku sekolah vokasional aliran agama yang bertujuan untuk melatih imam, pembaca khutbah, penceramah, dan penjawat awam dalam sektor agama. Bagi pendokong sekular, Sekolah Imam-Hatip mampu mengancam prinsip sekularisme yang diasaskan oleh Atatürk. Dari satu sudut, perspektif ini mempunyai asasnya memandangkan wujud naratif yang berpandangan bahawa sekolah tersebut merupakan kesinambungan daripada madrasah yang telah wujud sejak era Uthmaniyyah lagi (Aşlamacı \& Kaymakcan 2016). Tidak kurang wujud juga tanggapan bahawa ia beroperasi sebagai pusat bagi melahirkan 'kaderkader Islam' yang akan menyelinap masuk ke dalam pelbagai sektor, tidak semata-mata sektor agama memandangkan kursus pengajian di sekolah tersebut turut memuatkan kursus-kursus akademik (Çakmak 2009). Manakala mereka yang menyokong Sekolah Imam-Hatip pula menghujahkan bahawa sekolah tersebut tidak bertentangan dengan prinsip sekularisme lantaran 
ia diwujudkan di bawah Undang-undang Tevhid-i Tedrisat Kanunu (Penyelarasan Pendidikan) semasa era Atatürk lagi (Öcal 2007).

Disebabkan wujud persepsi bahawa Sekolah Imam-Hatip bercanggah dengan prinsip sekularisme, terdapat beberapa usaha yang telah dilakukan bagi mengekang perkembangannya. Misalnya pada tahun 1997, penstrukturan sistem persekolahan telah dilaksanakan oleh 'kerajaan tentera sementara' dengan memanjangkan tempoh persekolahan wajib bagi para pelajar. Jika sebelumnya, pelajar-pelajar hanya diwajibkan untuk bersekolah di sekolah kebangsaan biasa bagi tempoh lima tahun di peringkat rendah sebelum dibenarkan untuk menyambung ke manamana jenis sekolah untuk tiga tahun di peringkat menengah, termasuklah ke Sekolah Imam-Hatip, penstrukturan sistem persekolahan yang diperkenalkan telah memanjangkan tempoh persekolahan wajib daripada lima tahun kepada lapan tahun, iaitu empat tahun sekolah rendah dan empat tahun sekolah menengah. Kesannya, pelajar-pelajar diwajibkan untuk menghabiskan tempoh persekolahan di sekolah kebangsaan biasa selama lapan tahun dan tidak dibenarkan untuk bersekolah di sekolah lain bagi peringkat menengah. Sistem yang diperkenalkan menyebabkan Sekolah Imam-Hatip tidak lagi relevan di peringkat menengah memandangkan pelajar-pelajar wajib menyelesaikan lapan tahun persekolahan di sekolah kebangsaan dan hanya dibenarkan untuk ke sekolah lain bagi peringkat sekolah tinggi. Perkembangan tersebut menyebabkan akhirnya, Sekolah Imam-Hatip terpaksa ditutup bagi peringkat menengah berikutan penurunan mendadak pelajarnya pada sesi persekolahan seterusnya (Muhammad Khalis \& Mohd Roslan 2018).

Sepertimana pendiriannya dalam isu larangan bertudung, AKP turut berpegang kepada pendirian bahawa pendidikan tidak berkait dengan agenda menghakis prinsip sekularisme negara. Berdasarkan prinsip hak asasi, sesiapa sahaja berhak untuk mendapatkan sebarang bentuk pendidikan yang diingini, termasuklah pendidikan agama. Pendirian ini diterjemahkan menerusi usaha AKP dalam merungkai polemik yang bersabit dengan kedudukan Sekolah ImamHatip. Pada 20 Februari 2012, pihak kerajaan Turki telah mengemukakan usul di parlimen bagi merombak sistem persekolahan sedia ada kepada sistem persekolahan yang baharu. Usul tersebut telah dipersetujui secara majoriti dan dirangka sebagai undang-undang pendidikan baharu pada 30 Mac 2012 di bawah nama 'Undang-undang Bagi Meminda Undang-undang Pendidikan Peringkat Rendah' dan diwartakan secara rasmi pada 11 April 2012 yang membolehkannya berkuatkuasa serta-merta (Gün \& Baskan 2014). Sistem tersebut memberi kesan kepada pemanjangan tempoh persekolahan wajib daripada lapan tahun kepada 12 tahun iaitu empat tahun persekolahan peringkat rendah, empat tahun persekolahan peringkat menengah dan empat tahun persekolahan peringkat tinggi. Di samping memanjangkan tempoh persekolahan, sistem yang diperkenalkan turut memberi kesan kepada pengembalian fungsi Sekolah Imam-Hatip. Sistem tersebut antaranya memberi kebebasan kepada ibu bapa untuk menghantar anak mereka sama ada ke sekolah biasa atau ke sekolah vokasional seperti Sekolah Imam-Hatip bagi peringkat menengah. Perubahan ini memberi kesan kepada pertambahan mendadak bilangan Sekolah Imam-Hatip di seluruh Turki (Muhammad Khalis \& Mohd Roslan 2018).

\section{Cabaran AKP}

Aspek ketiga yang akan dianalisis ialah cabaran yang dihadapi oleh AKP. Dalam konteks cabaran yang dihadapi, AKP banyak menerima tentangan dan ancaman daripada pihak tentera. Di Turki, bidang kuasa dan dominasi tentera dalam bidang politik adalah cukup signifikan. Institusi tersebut tidak hanya berperanan dalam memastikan keselamatan negara terus terjamin, tetapi juga berperanan sebagai pemelihara gagasan sekularisme yang digariskan oleh Atatürk. Dalam hal ini, tentera diperuntukkan kuasa melalui Artikel 35 Kanun Perkhidmatan Luar Tentera Turki yang menyatakan bahawa 'tugas pasukan tentera ialah mempertahankan dan memelihara wilayah Turki dan Republik Turki sebagaimana yang termaktub di dalam perlembagaan' Melalui 
peruntukan tersebut, tentera berhak untuk mengambil sebarang tindakan yang difikirkan perlu jika mendapati kebajikan negara diabaikan oleh pemerintah atau prinsip sekularisme terancam (Muhammad Khalis \& Mohd Roslan 2019).

Di samping mempunyai kebebasan bagi melakukan sebarang tindakan yang difikirkan perlu di atas alasan 'memelihara keamanan negara,' tentera turut dilihat menjadi tonggak utama di sebalik perjalanan politik Turki. Tentera cukup licik dalam memposisikan dirinya di dalam spektrum pentadbiran negara sehingga institusi tersebut berupaya menikmati pelbagai keistimewaan. Jika pihak tentera mendapati kepentingan mereka dihakis hatta oleh rejim pemerintah sekalipun, mereka tidak teragak-agak untuk melakukan tindakan drastik, termasuklah dengan melakukan rampasan kuasa. Keberadaan tentera yang dilihat sebagai pemelihara kestabilan negara dan prinsip sekularisme menyebabkan rakyat Turki memberi kepercayaan kepada tentera dalam menangani sebarang ancaman luar mahupun dalam (Mohammad Redzuan \& Mashitah 2015). Peruntukan di dalam perundangan serta kepercayaan masyarakat memberikan keabsahan kepada tentera untuk melakukan sebarang tindakan bagi mencapai keamanan negara, termasuklah tindakan-tindakan yang bertentangan dengan nilai demokasi.

Meskipun telah mengendurkan pendekatannya, AKP tidak dapat mengelak daripada berhadapan dengan ancaman pihak tentera. Komitmen AKP dalam memelihara prinsip sekularisme sentiasa dicurigai lantaran ia dilihat cenderung terhadap dasar-dasar konservatif dan mesra-Islam, di samping sejarah keterlibatan pemimpin-pemimpin utamanya dengan gerakan politik Islam sebelumnya. Komplot Ergenekon merupakan episod penting yang menyaksikan perseteruan tentera terhadap AKP. Ergenekon merupakan satu komplot terancang yang bertujuan untuk mensabotaj pentadbiran AKP dengan mencetuskan huru-hara di seluruh Turki bagi menjustifikasikan campur tangan tentera secara langsung dalam urusan pentadbiran negara. Menurut Syarif Taghian (2013), komplot tersebut melibatkan anggota tentera, pesara tentera, ahli akademik, wartawan, badan perisikan, ahli birokrat, ahli parlimen, badan kehakiman serta pertubuhan sivil. Meskipun banyak sektor yang terlibat, peranan jaringan tentera adalah yang paling menonjol dalam komplot tersebut. Jaringan Ergenekon sukar untuk dijejaki memandangkan ia terdiri daripada pelbagai bahagian yang terpisah dan bergerak secara rahsia di bawah beberapa pengarah. Selain itu, sebahagian penggerak Ergenekon turut menyusup ke dalam pelbagai lembaga dan badan-badan rasmi kerajaan bagi mengaburi mata pemerintah dan pihak keselamatan.

Walau bagaimanapun, komplot Ergenekon akhirnya berjaya dihidu oleh pihak keselamatan Turki melalui pendedahan yang dilakukan oleh Nokta iaitu sebuah majalah bebas, pada Mac 2007. Berdasarkan pendedahan majalah tersebut, tentera didapati telah merancang untuk melakukan rampasan kuasa sebanyak dua kali sejak tahun 2004 (Mohammad Redzuan \& Mashitah 2015). Siasatan secara terperinci telah dilakukan untuk menjejaki dalang-dalang Ergenekon dan mendapati beberapa siri kes pengeboman di lokasi-lokasi tertentu mempunyai kaitan rapat dengan jaringan tersebut. Di samping itu, 12 rancangan untuk membunuh Erdoğan serta beberapa perancangan lain bagi mencetuskan provokasi di seluruh Turki turut berjaya dibongkar (Syarif Taghian 2013). Proses penangkapan dan perbicaraan kes Ergenekon telah dilakukan secara agresif sekitar tahun 2007-2011 yang melibatkan pendakwaan sejumlah individu berprofil tinggi.

'Operasi pembersihan' yang dilakukan menerusi pembicaraan kes Ergenekon tidak menamatkan kegiatan subversif tentera. Sebaliknya, segelintir daripada mereka telah meneruskan perencanaan bagi memastikan matlamat menjatuhkan AKP tercapai. Per encanaan tersebut telah diterjemahkan menerusi cubaan rampasan kuasa tentera yang dilakukan pada 15 Julai 2016. Cubaan rampasan kuasa tersebut merupakan satu peristiwa yang tragik dalam sejarah Turki moden di mana pihak tentera yang terlibat telah menembak secara rambang rakyat yang turun ke jalan raya. Malah, bangunan parlimen dan hotel di mana Erdoğan menginap telah diserang oleh kapal udara tentera. Erdoğan berjaya menyelamatkan diri lebih awal sebelum 
serangan dilakukan dan mengerahkan lebih ramai rakyat untuk turun ke jalan raya bagi mempertahankan demokrasi Turki. Kebanjiran rakyat di jalan raya, di samping tentangan daripada pihak keselamatan dan tentera Turki yang masih setia dengan kerajaan menyebabkan tentera yang cuba melakukan rampasan kuasa menghadapi kebuntuan. Cubaan rampasan kuasa tersebut akhirnya berjaya digagalkan selepas beberapa jam operasi bermula.

\section{Identiti AKP di Persimpangan Jalan}

Secara umumnya dapat dinyatakan bahawa ideologi AKP adalah berpaksikan kepada ciri-ciri berikut: i) AKP menjadikan konservatif demokrasi sebagai ideologi parti dengan mengharmonikan nilai-nilai konservatif dengan nilai-nilai demokrasi liberal; ii) AKP mengiktiraf sekularisme dan komited untuk memelihara sekularisme sebagai identiti negara Turki. Namun, sekularisme yang diiktiraf oleh AKP adalah sekularisme berasaskan tafsiran yang lebih liberal dan demokratik, termasuklah dalam memelihara hak rakyat untuk melaksanakan tuntutan agama; dan iii) untuk menterjemahkan tafsiran sekularisme tersebut, AKP menjadikan usaha pendemokrasian serta penyertaan Turki ke dalam EU sebagai agenda utamanya.

Jika dibuat perbandingan antara ideologi AKP dan gerakan politik Islam khususnya dalam konteks Turki, adalah didapati bahawa AKP hampir memenuhi kesemua ciri-ciri bagi sebuah gerakan politik Islam. Pertama, AKP boleh disifatkan sebagai sebuah gerakan massa yang merungkai isu-isu yang melanda. Menurut Cagaptay (2017), AKP diberi kepercayaan oleh rakyat dalam pilihan raya tahun 2002 kerana diyakini mampu menyelesaikan krisis politik dan ekonomi yang melanda Turki. Pertumbuhan ekonomi Turki yang memberangsangkan serta proses reformasi politik menerusi usaha pendemokrasian membuktikan komitmen AKP dalam menyelesaikan permasalahan semasa (Mohammad Redzuan \& Mashitah 2015). Kedua, AKP juga merupakan sebuah entiti arus perdana. Hal ini dapat dibuktikan menerusi mandat yang diberikan oleh rakyat yang menjadi sumber legitimasi untuk parti tersebut terus memerintah. Ciri-ciri arus perdana AKP dijelaskan lagi menerusi segmen pengundi AKP yang luas iaitu meliputi kelompok pro-Islam, pendokong liberal, pengundi jalur tengah-kanan, dan mereka yang menyokong gagasan demokrasi (Şimșek 2013). Ketiga, AKP turut menekankan pendekatan yang bersifat praktikal berbanding ideologi. Menurut Rabasa \& Larrabee (2008), pengamalan kehidupan seharian yang menepati nilai-nilai moral lebih ditekankan oleh AKP berbanding retorik ideologikal, termasuklah untuk membina sebuah negara Islam. Walau bagaimanapun, AKP dilihat tidak menonjolkan aspirasi agama menerusi wacananya secara langsung, di mana unsur agama hanya dirangkum secara tidak langsung di bawah jenama konservatisme. Manakala berhubung dengan wacana tradisi pula, meskipun ia tidak terzahir secara jelas pada batang tubuh AKP, konservatif demokrasi yang bersifat akomodatif dan inklusif boleh ditafsir sebagai natijah daripada rasionalisme teologi Maturidiah, universalisme mazhab Hanafi dan semangat toleransi Sufisme yang telah bersebati sebagai norma sosial di Turki. Kekangan perundangan yang melarang penonjolan elemen agama mendesak AKP untuk mengadaptasi ideologi konservatif demokrasi bagi menengahi antara dua kutub yang berbeza iaitu antara keperluan memelihara elemen-elemen konservatisme seperti agama dan moral masyarakat pada satu sudut, dan keperluan memelihara keberlangsungan parti di sudut yang lain

Pada masa yang sama, AKP turut berpegang kepada idea sekularisme yang mungkin mewujudkan pertikaian. Jika AKP merupakan sebuah parti yang mempunyai aspirasi agama, bagaimana ia turut mempunyai komitmen terhadap sekularisme pada masa yang sama? Senario ini boleh difahami dengan mengambil kira realiti negara Turki yang sememangnya berpegang kuat kepada prinsip sekularisme serta naratif sekularisme yang dibawa oleh AKP. Menurut Artikel 2 Perlembagaan Turki, prinsip sekularisme dinyatakan dengan jelas sebagai identiti negara. Namun, bentuk atau naratif sekularisme secara spesifik tidak dijelaskan. Kelompangan ini membuka ruang kepada tafsiran terhadap prinsip sekularisme di mana menurut AKP, sekularisme yang sewajarnya menjadi pegangan Turki adalah sekularisme yang memelihara nilai 
kebebasan rakyat, bukan sekularisme yang bersifat autoritarian dan mencengkam (Sambur 2009). Ini kerana sekularisme seperti yang termaktub di dalam perlembagaan, merupakan prinsip negara, sekaligus tidak sewajarnya dipaksakan kepada individu (Kuru 2008). Dalam hal ini, rasionaliti di sebalik penonjolan sekularisme berdasarkan olahan yang lebih liberal oleh AKP adalah untuk menjelaskan kekaburan yang berlegar pada takrifan dan pengamalan sekularisme di Turki.

Berhubung sikap terhadap isu larangan bertudung dan pendidikan agama, AKP didapati telah memperlihatkan sikap memihak kepada kepentingan agama dalam kedua-dua isu tersebut. Bermula pada tahun 2008 dengan cubaan memansuhkan Artikel 10 dan Artikel 42 di dalam Perlembagaan Turki, larangan bertudung akhirnya berjaya dimansuhkan secara rasmi pada Oktober 2013. Larangan bertudung merupakan isu yang penting di Turki lantaran ia memperlihatkan kekaburan sempadan antara ruang awam dan ruang privasi. Secara teorinya, prinsip sekularisme merupakan mekanisme bagi mewujudkan sempadan antara ruang awam dan ruang privasi, di mana urusan keagamaan adalah tertakluk di bawah hal ehwal peribadi. Walau bagaimanapun, tudung telah menjadi subjek pertikaian berhubung statusnya sama ada ia terletak di bawah ruang lingkup awam atau peribadi. Misalnya, larangan pemakaian tudung yang terpakai di universiti menimbulkan pertikaian kerana dari satu sudut, universiti merupakan premis awam yang perlu dipelihara persekitaran sekularnya. Namun, mereka yang menyokong pemakaian tudung pula menghujahkan bahawa pemakaian tudung merupakan urusan peribadi yang tertakluk di bawah hak privasi. Secara asasnya, konflik mengenai pemakaian tudung yang berpanjangan sejak ia diharamkan pada penghujung tahun 70 -an adalah bertitik-tolak daripada kekaburan sempadan antara ruang awam dan ruang privasi di Turki. Penulis berpendapat, di sini letaknya peri penting naratif sekularisme AKP yang lebih liberal dan demokratik untuk merungkai isu larangan bertudung kerana ia tidak semata-mata berkait mengenai subjek tudung, akan tetapi turut berkait dengan perbahasan mengenai pengamalan sekularisme di Turki secara keseluruhan. Dalam hal ini, pemansuhan larangan bertudung bermula pada Oktober 2013 merupakan simbolik kepada perungkaian konflik sempadan ruang awam dan ruang privasi di Turki.

Dalam isu pendidikan agama pula, AKP telah mengembalikan semula peranan Sekolah Imam-Hatip di peringkat menengah yang ditutup sebelumnya kesan daripada penstrukturan sistem persekolahan bermula pada tahun 1997. Penulis melihat, usaha mengembalikan semula fungsi Sekolah Imam-Hatip merupakan manifestasi kepada paradigma konservatif AKP. Selaku entiti yang mengangkat nilai-nilai konservatisme, pengajaran agama yang diajarkan di Sekolah Imam-Hatip semestinya turut mendapat perhatian khusus AKP kerana ia menterjemahkan sentimen keagamaan sekolah tersebut. Tambahan pula, Sekolah Imam-Hatip turut disebutkan sebagai merupakan kesinambungan daripada madrasah yang telah wujud sebelum era republik lagi (Aşlamacı \& Kaymakcan 2016). Di samping itu, pengembalian semula fungsi Sekolah ImamHatip turut menyerlahkan aspirasi AKP terhadap nilai kepelbagaian. Dalam hal ini, pembukaan semula sekolah tersebut boleh ditafsir sebagai langkah AKP bagi memastikan supaya sekolah tersebut mampu untuk bersaing dengan sekolah kebangsaan biasa, sekaligus merancakkan lagi pendidikan di Turki. Langkah tersebut membolehkan wujudnya pilihan alternatif bagi ibu bapa yang menghantar anak-anak mereka ke sekolah, di mana mereka tidak lagi terikat dengan sekolah biasa seperti sebelumnya. Menurut laporan yang telah dikeluarkan oleh Biro Demokrasi, Hak Asasi dan Pekerja Amerika Syarikat pada tahun 2006, tidak semua ibu bapa yang memilih Sekolah Imam-Hatip supaya anak-anak mereka menjadi penjawat sektor agama. Sebahagiannya memilih sekolah tersebut untuk memastikan anak-anak mereka mendapat pendidikan agama yang secukupnya secara formal, dan pada masa yang sama tidak ketinggalan untuk memperoleh ilmu akademik biasa (Bureau of Democracy, Human Rights, and Labor 2006). Dengan ini, pembukaan semula Sekolah Imam-Hatip mampu memenuhi permintaan sebahagian ibu bapa yang menginginkan pendidikan agama secara formal untuk anak-anak mereka. 
Dalam konteks cabaran pula, adalah jelas bahawa AKP menghadapi ancaman daripada pihak tentera. Di Turki, institusi tentera mempunyai dua peranan utama, iaitu menjaga keselamatan negara serta memelihara prinsip sekularisme. Pemeliharaan prinsip sekularisme sangat bersebati dengan tugas tentera kerana prinsip tersebut dianggap sebagai sebahagian daripada agenda memelihara kestabilan dan keselamatan negara. Dengan ini, sebarang unsur yang ditafsir oleh tentera sebagai mengancam prinsip sekularisme akan dibasmi serta-merta. Menurut Sakallioğlu (1997), persepsi yang mendominasi ruang wacana tentera sejak tahun 90an ialah 'Islam merupakan ejen pemisah' sepertimana sektarianisme dan nasionalisme Kurdi, yang dianggap boleh menggugat keselamatan dan perpaduan negara. Disebabkan itu, adalah menjadi kelaziman bagi entiti yang mendokong agenda agama menghadapi tentangan daripada pihak tentera.

Oleh itu, timbul pula persoalan mengenai bagaimana pertembungan antara AKP dan pihak tentera boleh berlaku sedangkan AKP bukanlah sebuah parti yang menjelaskan aspirasi agamanya? Penulis berpandangan senario penentangan pihak tentera terhadap AKP mempunyai persamaannya dengan penentangan pihak tentera terhadap pentadbiran beberapa parti dari jalur tengah-kanan (centre-right) sebelumnya. Jika disoroti sejarah rampasan kuasa tentera pada tahun 1960 dan 1971, kerajaan ketika itu masing-masing dipimpin oleh Demokrat Partisi (Parti Demokrat-DP) dan Adalet Partisi (Parti Keadilan-AP); kedua-duanya bukanlah parti beraspirasikan agama, sebaliknya merupakan parti berhaluan tengah-kanan. Dalam konteks Turki, parti berhaluan tengah-kanan secara lazimnya merupakan parti berideologi konservatif dan membawa naratif sekularisme yang lebih liberal, berbeza dengan parti berhaluan tengah-kiri (centre-left) seperti CHP yang cenderung kepada sekularisme berjalur keras. Dalam hal ini, penulis berpendapat bahawa penentangan tentera terhadap AKP, sepertimana DP dan AP, adalah disebabkan naratif sekularisme liberal yang dibawa oleh mereka, di mana ia mampu mempengaruhi kedudukan dan pengamalan agama masyarakat.

Berdasarkan ideologi, sikap terhadap isu-isu terpilih serta cabaran yang dihadapi, penulis lebih cenderung untuk tidak mengkategorikan AKP sebagai sebuah gerakan politik Islam. Meskipun memenuhi hampir kesemua ciri-ciri sebuah gerakan politik Islam dalam konteks Turki, AKP tidak menonjolkan aspirasi agama secara jelas, sebaliknya lebih menonjolkan konservatif demokrasi yang longgar secara ideologinya sebagai pembawaan parti. Tambahan pula, AKP juga menjunjung sekularisme yang berpaksikan idea pemisahan agama daripada urusan politik dan kenegaraan. Hal ini menggambarkan bahawa AKP tidak berpegang kepada visi politik Islam yang jelas, iaitu premis asas bagi sebuah gerakan politik Islam, lantaran ia lebih cenderung kepada idea keneutralan politik daripada elemen keagamaan. Penulis berpandangan, AKP merupakan sebuah parti tersendiri yang 'menengahi' antara domain gerakan politik Islam dan domain sekular.

Dari satu sudut, AKP didapati lebih hampir kepada pasca Islamisme. Pegangannya terhadap idea demokrasi konservatif yang merangkumi idea-idea liberal, pro-EU dan menjunjung sekularisme adalah selari dengan prinsip pasca Islamisme yang cenderung kepada penafsiran semula wacana politik Islam kepada tafsiran yang lebih liberal dan moden. Malah, AKP itu sendiri diwujudkan sebagai respons dan kritikan terhadap gerakan politik Islam Milli Görüş yang didakwa sudah menemui kebuntuan dan ketepuan wacana. Pengadaptasian ideologi demokrasi konservatif juga didapati merupakan satu idea yang asing dan sekaligus boleh dihujahkan sebagai satu bentuk penyimpangan daripada wacana gerakan politik Islam.

Secara dasarnya, AKP hampir memenuhi kesemua ciri-ciri sebuah gerakan politik Islam dalam konteks Turki seperti yang telah dinyatakan. Namun, penulis cenderung untuk tidak mengkategorikan AKP sebagai gerakan politik Islam lantaran ia tidak menonjolkan aspirasi agama secara jelas, sebaliknya lebih menonjolkan konservatif demokrasi sebagai ideologi parti. Meskipun AKP memperlihatkan sikap yang memihak kepada kepentingan agama dalam beberapa isu, penulis berpandangan bahawa ia merupakan cerminan kepada aspirasi pendemokrasian yang cuba diketengahkan oleh parti tersebut. Berhubung dengan cabaran atau tentangan daripada pihak tentera pula, penulis menganalisis ia sebagai senario yang sama sebagaimana 
yang pernah dihadapi oleh parti-parti berhaluan tengah-kanan sebelumnya. Dengan ini, penulis menghujahkan bahawa AKP merupakan sebuah parti yang tersendiri berdasarkan ideologi konservatif demokrasi, di mana ia menjunjung sekularisme liberal dan cenderung mewujudkan suasana yang akomodatif untuk masyarakat Turki mengamalkan tuntutan agama secara bebas. Ideologi ini adalah selari dengan pasca Islamisme yang cenderung kepada prinsip-prinsip liberal dan moden.

\section{References}

Ahmad Dzakirin. 2012. Kebangkitan Gerakan Islam Analisis Strategi dan Polisi AKP Turki Memenangi Pilihanraya Umum. Kuala Lumpur: Alam Raya Enterprise.

AK PARTİ. 2015. Democratization and human rights package. (online) https://perma.cc/Q2GWTQDN [18 September 2019].

Akoglu, K. S. 2015. Piecemeal freedom: Why the headscarf ban remains in place in Turkey. Boston College International \& Comparative Law Review 38(2): 277-304.

Ahmad Munawar Ismail, Wan Kamal Mujani \& Ahmad Aiman Zuhaily A.M. 2018. Methods of Da'wah and social networks in dealing with liberalism and extremism. Islamiyyat-The International Journal of Islamic Studies 40(2): 131-139.

Ahmad Sunawari Long. 2017. Kebangkitan Semula Islam hingga Pasca Islamisme. Bangi: Penerbit UKM.

Alahmed, Ahmad Y. M \& Wan Kamal Mujani. 2015. Policy of Turkish justice and development party (Adalet ve Kalkınma Partisi) in internal reform. Mediterranean Journal of Social Sciences 6(4S1): 318-324.

Alahmed, Ahmad Y. M., Wan Kamal Mujani, Eeman Mohammed Abbas. 2015b. Turkey and European Union: objectives and obstacles. Mediterranean Journal of Social Sciences 6(4S1): 475-480.

Aşlamacı, I. \& Kaymakcan, R. 2017. A model for Islamic education from Turkey: The Imam-Hatip schools. British Journal of Religious Education 39(3): 279-292.

Ayoob, M. 2008. The Many Faces of Political Islam Religion and Politics in the Muslim World. Singapore: NUS Press.

Bayat, A. 1996. The coming of a post-Islamist society. Critique: Journal for Critical Studies of the Middle East 5(9): 43-52.

Bayat, A. 2005. Islamism and social movement theory. Third World Quarterly 26(6): 891-908.

Bureau of Democracy, Human Rights, and Labor. 2006. Turkey: international religious freedom report 2006. U.S. Department of State. (online) https://www.state.gov/j/drl/rls/irf/2006/71413.htm [9 February 2018].

Cagaptay, S. 2017. The New Sultan Erdogan and the Crisis of Modern Turkey. London: I.B. Tauris.

Çakmak, D. 2009. Pro-Islamic public education in Turkey: The Imam-Hatıp schools. Middle Eastern Studies 45(5): 825-846.

Cindoglu, D. \& Zencirci, G. 2008. The headscarf in Turkey in the public and state spheres. Middle Eastern Studies 44(5): 791-806.

Denoeux, G. 2002. The forgotten swamp: Navigating political Islam. Middle East Policy 9(2): 5681.

Erdogan, R. T. 2004. Conservative democracy and the globalisation of freedom. American Enterprise Institute, 29 January. (online) https://www.c-span.org/video/?1803111/democracy-turkey [17 July 2019].

Fuller, G. E. 2003. The Future of Political Islam. New York: Palgrave Macmillan.

Gün, F. \& Baskan, G. A. 2014. New education system in Turkey $(4+4+4)$ : A critical outlook. Procedia-Social and Behavioral Sciences 131: 229-235.

Köni, H. \& Açıkgöz, M. 2013. Politics of religion in Turkey from national view to the justice and development party. International Journal of Research in Social Sciences 3(2): 48-56. 
Kuru, A. T. 2008. Secularism in Turkey: myths and realities. Insight Turkey 10(3): 101-110.

Maszlee Malik. 2016. Pasca-Islamisme atau wacana baru gerakan Islam? In. Maszlee Malik \& Zulkifli Hasan (eds.). Generasi Kedua Politikal Islam Wacana Baru Gerakan Islam, Vol. 1, pp. 3-13. Selangor: Ilham Books.

Mohammad Redzuan Othman \& Mashitah Sulaiman. 2015. Sekularisme dan Proses Demokrasi di Turki Pemerkasaan Islam dan Kepimpinan Erdogan. Kuala Lumpur: Penerbit Universiti Malaya.

Muhamad Razak Idris. 2016. Politikal Islam dan Persimpangan Masa Depan. Selangor: Ilham Books.

Muhammad Khalis Ibrahim \& Mohd Roslan Mohd Nor. 2018. Cabaran pendidikan Islam di Turki: usaha AKP terhadap pemerkasaan sekolah Imam-Hatip. International Journal of West Asian Studies 10(1): 1-12.

Muhammad Khalis Ibrahim \& Mohd Roslan Mohd Nor. 2019. Perkembangan Islamisasi di Turki era Erdoğan (2002-2010): pendekatan, usaha dan cabaran. Akademika: Journal of Southeast Asia Social Sciences and Humanities 89(1): 45-55.

Öcal, M. 2007. From the past to the present: Imam and preacher schools in Turkey - an ongoing quarrel. Religious Education 102(2): 191-205.

Özbudun, E. 2012. Turkey's search for a new constitution. Insight Turkey 147(1): 39-50.

Oztig, L. I. 2018. The Turkish constitutional court, laicism and the headscarf issue. Third World Quarterly 39(3): 594-608.

Rabasa, A. \& Larrabee, F. S. 2008. The Rise of Political Islam in Turkey. California: RAND Corporation.

Sakallioğlu, Ü. C. 1997. The anatomy of the Turkish military's political autonomy. Comparative Politics. 29(2): 151-166.

Saktanber, A. \& Çorbacioğlu, G. 2008. Veiling and headscarf-skepticism in Turkey. Social Politics. 15(4): 514-538.

Sambur, B. 2009. The great transformation of political Islam in Turkey: The case of justice and development party and Erdogan. European Journal of Economic and Political Studies 2(2): 117-127.

Şimşek, S. 2013. Conservative democracy as a cosmetic image in Turkish politics: The semiology of AKP's political identity. Turkish Studies 14(3): 429-446.

Syarif Taghian. 2013. Recep Tayyip Erdogan Pembela Rakyat, Membangun Pemerintahan Bersih, Meruntuhkan Sekularisme Turki. Kuala Lumpur: Alam Raya Enterprise.

Uğur, U. 2004. Intellectual roots of 'Turkish Islam' and approaches to the 'Turkish model.' Journal of Muslim Minority Affairs 24(2): 327-345.

Vahide, S.. 2011. Bediuzzaman Said Nursi: Author of the Risale-i Nur. Selangor: Islamic Book Trust. Wan Ahmad Fahmi Wan Muda. 2017. Pemikiran pasca Islamisme dalam konteks gerakan Islam di Malaysia. Jurnal Hadhari 9(2): 309-319.

Wan Kamal Mujani, Ahmed Y.M. Alahmed \& Eeman Mohammed Abbas. 2015. Turkish foreign policy trends since 2002. Mediterranean Journal of Social Sciences 6(4S1): 400-405.

Ylldız, A. 2010. Problematizing the intellectual and political vestiges from 'welfare' to 'justice and development'. In. Ümit Cizre (ed.). Secular and Islamic Politics in Turkey the Making of the Justice and Development Party, pp. 41-61. London: Routledge. 